DOI: $10.6060 / \mathrm{mhc} 2012.121192 \mathrm{k}$

\title{
Covalent Conjugates of Ammine and Diamine Platinum(II) with Zinc(II) Octacarboxyphthalocyanine
}

\author{
Roman A. Bulgakov, ${ }^{a}$ Nina A. Kuznetsova, ${ }^{a}$ Olga V. Dolotova, ${ }^{a}$ \\ Ekaterina N. Shevchenko, ${ }^{a}$ Anna D. Plyutinskaya ${ }^{b}$, Oleg L. Kaliya ${ }^{a}$ \\ and Tebello Nyokong ${ }^{c}$
}

Dedicated to Academician Aslan Tsivadze on the occasion of his 70th Anniversary

\begin{abstract}
${ }^{\mathrm{a}}$ Organic Intermediates and Dyes Institute, 123995 Moscow, Russia
${ }^{\mathrm{b}} \mathrm{P}$. A. Hertsen Moscow Research Institute of Oncology, 125284 Moscow, Russia

${ }^{\circ}$ Department of Chemistry, Rhodes University, Grahamstown 6140, South Africa

@Corresponding authorE-mail:lab32@niopik.ru
\end{abstract}

\begin{abstract}
Covalent conjugates of ammine and diamine platinum(II) and octacarboxy substituted zinc phthalocyanine bearing one, two, three and four ammine platinum and ethylenediamine- $N, N$ '-diacetic acid platinum moieties on the periphery of the Pc ligand have been synthesized and characterized. Complexes with two and three ammine platinum fragments and all diamine compounds have been synthesized for the first time. The solubility of conjugates with diamine platinum in aqueous solutions is higher than that for their ammine counterparts and for both series it significantly decreases as the number of platinum atoms increases. The effect of the stepwise introduction of the ammine and diamine platinums on the dynamics of the singlet and triplet excited states, on the ability to sensitize singlet oxygen formation and on the photostability of these compounds has been investigated in dimethylsulfoxide solution. Both ammine and diamine platinum moieties have only a limited effect on the photophysical and photochemical properties. Conjugates sensitize the formation of singlet oxygen with high quantum yields $\left(\Phi_{\Delta}=0.47-0.60\right)$ and show higher activity in photoinactivation of cancer cells and cytotoxicity than parent octacarboxy-substituted PcZn.
\end{abstract}

Keywords: Zinc octacarboxyphthalocyanine, covalent conjugate, platinum, singlet oxygen, photostability, photocytotoxicity.

\section{Ковалентные коньюгаты аммино и диамино платины(II) и октакарбоксифталоцианина цинка(II)}

\author{
P. А. Булгаков, ${ }^{a}$ Н. А. Кузнецова, ${ }^{a}{ }^{@}$ О. А. Аолотова, ${ }^{a}$ Е. Н. Шевченко, ${ }^{a}$ \\ А. А. Плютинская, ${ }^{\mathrm{b}}$ О. А. Калия, ${ }^{\mathrm{a}}$ Т. Ниоконг
}

Посвящается акаgемику Аслану Юсуповичу Циваgзе по случаю его 70-летнего юбилея

${ }^{\mathrm{a}}$ Государственный научный ичентр «НИОПИК», 123995 Москва, Россия

${ }^{\mathrm{b}}$ Московский научно-исследовательский онкологический институт им. П. А. Гериена, 125284 Москва, Россия

'Department of Chemistry, Rhodes University, 6140 Грахамстаун, ЮАР

@E-mail: lab32@niopik.ru

Синтезированы и охарактеризованы моно-, ди-, три-и тетразамещеенные ковалентные конъюгаты платины((II) и октакарбоксифталоцианина циика с координированными по платине лигандами $\mathrm{NH}_{3}$ и ЕDDA (этилендиаминN,N’-диуксусная кислота). Ди- и тризамещенные амминосодержащие, а также все диамино комплексы 
синтезированы впервые. Растворимость в воде коньюгатов с диамино платиной выше, чем соответствующих амминосодержаших аналогов и для обеих серий соединений она снижается при увеличении количества атомов платины. Влияние ступенчатого введения аммино- и диамино платины на динамику синглетных и триплетных возбужденных состояний, на способность сенсибилизировать образование синглетного кислорода и фотостабильность коньюгатов исследовалось в диметилсульфоксиде. Как аммино, так и диамино платиновые фрагменты практически не влияют на фотофизические и фотохимические свойства коньюгатов. Коньюгаты сенсибилизируют образование синглетного кислорода с высокими квантовыми выходами (Ф 0.47 - 0.60) и проявляют более высокую фото- и циитотоксичность по сравнению с исходным октакарбоксифталоциианном цинка.

Ключевые слова: Октакарбоксифталоцианинат цинка, ковалентные конъюгаты, платина, синглетный кислород, фотостабильность, фотоцитотоксичность.

\section{Introduction}

As was discussed in our previously reported publication $^{[1]}$ the covalent conjugates $(\mathrm{CCs})$ of cytotoxic $\mathrm{Pt}^{\mathrm{II}}$ complexes and porphyrinoids are promising candidates for the development of novel dual action anticancer drugs, which can act as photosensitizers and chemotherapeutics.

After first attempts to combine the cytotoxic activity of platinum preparations with the phototoxicity of porphyrin derivatives in a single molecule carried out by Brunner and Obermeier in 1994[2] few reports on the Pc ligand containing $\mathrm{CCs}$ with $\mathrm{Pt}^{\mathrm{II}}$ have been appeared. The first examples were published by V. Nemykin and co-workers in 2000 and it was described only the synthesis of zinc tetrakis(cis-[(3-oxypyridyl)-N]amminedichloroplatinum(II)) $\mathrm{Pc}$ and zinc tetrakis(cis-[(3-oxypyridyl)- $N]$ dichloro[sulfonylbis(methane)-S]platinum(II))Pc. ${ }^{[3]}$ Next and the last publication of this group appeared in 2003 and it also reported the synthesis of $\mathrm{CCs}$ of $\mathrm{Pt}^{\mathrm{II}}$ and octacarboxysubstituted PcZn, containing ammine (1 and 4 Pt moieties) and dimethylsulfoxide (DMSO) (1 and $4 \mathrm{Pt}$ moieties). ${ }^{[4]}$ Synthesis of ethylenediamine- $N, N^{\prime}$-diacetic acid complexes of the covalent conjugates of octacarboxy-substituted cobalt phthalocyanine with one, two and three platinum atoms was carried out in our laboratory. ${ }^{[5]}$ Investigations of photophysical properties or medical tests were not reported for these compounds, however.

It has been previously demonstrated that octacarboxysubstituted zinc phthalocyanine is markedly photocytotoxic and sensitizes the formation of singlet oxygen, the chief cytotoxic species in photodynamic therapy (PDT), with a quantum yield $\varphi_{\Delta}=0.57 .{ }^{[6]}$ As stated in our previously reported paper, ${ }^{[1]}$ its covalent conjugates with aqua platinum(II), bearing one, two, three and four aqua platinum fragments, efficiently sensitize singlet oxygen formation and thus show potential as dual action anticancer drugs. However, strong aggregation of conjugates with aqua platinum impedes their application in aqueous and biological media. The goals of this study were to synthesize a series of octacarboxysubstituted PcZns bearing from one to four ammine or diamine platinum(II) fragments and to investigate their solubility in aqueous media and how the conjugated ammine and diamine platinum(II) moieties affect the behavior of the $S_{1}$ and $T_{1}$ excited states, photostability and the singlet oxygen quantum yield.

\section{Experimental}

\section{Materials}

The sodium salt of zinc 2,3,9,10,16,17,23,24octacarboxyphthalocyanine was synthesized using literature methods. ${ }^{[7,8]}$ Zinc phthalocyanine (PcZn) was obtained from the Research Institute of Organic Intermediates and Dyes (NIOPIK), Russian Federation, as a trade reagent. High-purity grade cisplatin (cis-Pt $\left(\mathrm{NH}_{3}\right)_{2} \mathrm{Cl}_{2}$, Aldrich), ethylenediamine- $N, N^{\prime}$-diacetic acid (EDDA, Aldrich), singlet oxygen trap 1,3-diphenylisobenzofuran (DPBF, Fluka) and dimethylsulfoxide (DMSO, Sigma-Aldrich) were used as received without further purification.

Synthesis of covalent conjugates of ammine platinum(II) with octacarboxy substituted zinc phthalocyanine (1a-d):

a) diammine $[9,10,16,17,23,24$-hexacarboxyphthalocyaninatozinc(II)-2,3-dicarboxylato]-platinum(II) hexasodium salt, $\mathrm{Pc} \mathrm{ZnPt}\left(\mathrm{NH}_{3}\right)_{2}(\mathbf{l a})$. Synthesis was carried out by the method reported earlier. ${ }^{[4]}$ Found: C 38.01, H 1.96, N $11.19 \% . \mathrm{C}_{40} \mathrm{H}_{14} \mathrm{~N}_{10} \mathrm{O}_{16} \mathrm{ZnPtNa}_{6}$ requires $\mathrm{C} 37.27, \mathrm{H} 1.09, \mathrm{~N}$ 10.87. IR $(\mathrm{KBr}) v_{\max } \mathrm{cm}^{-1}: 1414.6$, 1441.3, 1487, 1559.5, 1620.5. UV-vis (DMSO) $\lambda_{\text {max }}$ nm: 360, 697.

b) tetraammine- $\mu$-[16(9),17(10),23,24-tetracarboxyphthalocyaninatozinc(II)-2,3,9(16),10(17)-tetracarboxylato] diplatinum(II) tetrasodium salt, $\mathrm{Pc}^{\prime} \mathrm{ZnPt}_{2}\left(\mathrm{NH}_{3}\right)_{4}(\mathbf{l b})$. The same procedure was used as in ${ }^{[4]}$ but using the solution of cis- $\mathrm{Pt}\left(\mathrm{NH}_{3}\right)_{2} \mathrm{Cl}_{2}$ (27.1 mg, $0.09 \mathrm{mmol})$ in distilled water $(18 \mathrm{ml}), \mathrm{AgNO}_{3}(30.7 \mathrm{mg}$, $0.18 \mathrm{mmol}$ ) dissolved in the minimum volume of water and Pc' $\mathrm{Zn}$ $(50 \mathrm{mg}, 0.045 \mathrm{mmol})$ in distilled water $(10 \mathrm{ml})$. Yield: $49.4 \mathrm{mg}$ (65 \%). Found: C 30.84, H 2.86, N $10.91 \%$. $\mathrm{C}_{40} \mathrm{H}_{20} \mathrm{~N}_{12} \mathrm{O}_{16} \mathrm{ZnPt}_{2} \mathrm{Na}_{4}$ requires C 30.40, H 2.04, N 10.64. IR (KBr) $v_{\max } \mathrm{cm}^{-1}$ : 1448.9, 1487.0, 1570.9, 1635.7, 1704.4. UV-vis (DMSO) $\lambda_{\text {max }} \mathrm{nm}: 359$, 698.

c) hexaammine- $\mu^{3}-[23,24$-dicarboxyphthalocyaninatozinc(II)-2,3,9,10,16,17-hexacarboxylato]-triplatinum(II) disodium salt, $\mathrm{Pc}^{\prime} \mathrm{ZnPt} \mathrm{N}_{3}\left(\mathrm{NH}_{3}\right)_{6}(\mathbf{l c})$. The same procedure was used as in ${ }^{[4]}$ but using the solution of cis- $\mathrm{Pt}\left(\mathrm{NH}_{3}\right)_{2} \mathrm{Cl}_{2}(40.65 \mathrm{mg}, 0.135 \mathrm{mmol})$ in distilled water $(20 \mathrm{ml}), \mathrm{AgNO}_{3}(46.05 \mathrm{mg}, 0.27 \mathrm{mmol})$ dissolved in the minimum volume of water and Pc'Zn $(50 \mathrm{mg}, 0.045 \mathrm{mmol})$ in distilled water $(10 \mathrm{ml})$. Yield: $50.2 \mathrm{mg}(62 \%)$. Found: $\mathrm{C} 26.24, \mathrm{H}$ 2.82, $\mathrm{N} 11.08 \%$. $\mathrm{C}_{40} \mathrm{H}_{26} \mathrm{~N}_{14} \mathrm{O}_{16} \mathrm{ZnPt}_{3} \mathrm{Na}_{2}$ requires C 26.69, $\mathrm{H} 2.35, \mathrm{~N}$ 10.89. IR (KBr) $v_{\max } \mathrm{cm}^{-1}: 1441.3,1490.8,1559.5,1624.3,1700.6$. UV-vis (DMSO) $\lambda_{\text {max }} \mathrm{nm}: 360,698$.

d) octaammine- $\mu^{4}$-[phthalocyaninatozinc(II)-2,3,9,10,16,17, 23,24-octacarboxylato]-tetraplatinum(II), $\mathrm{Pc}^{\prime} \mathrm{ZnPt}_{4}\left(\mathrm{NH}_{3}\right)_{8} \quad$ (1d). Synthesis was carried out by the method reported earlier. ${ }^{\left[{ }^{3]}\right.}$ Found: $\mathrm{C} 26.24, \mathrm{H} 2.02, \mathrm{~N} 12.86 \%$. $\mathrm{C}_{40} \mathrm{H}_{32} \mathrm{~N}_{16} \mathrm{O}_{16} \mathrm{ZnPt}_{4}$ requires $\mathrm{C} 26.13, \mathrm{H}$ 1.75, N 12.19. IR (KBr) $v_{\max } \mathrm{cm}^{-1}: 1452.9,1568.6,1559.5,1631.2$, 1693.9. UV-vis (DMSO) $\lambda_{\text {max }} \mathrm{nm}: 361,696$.

Synthesis of diamine complexes of CC of platinum(II) with octacarboxy-substituted zinc phthalocyanine $(\mathbf{2 a}-\boldsymbol{d})$ :

a) $\left[k N^{2}-N, N^{\prime}\right.$-bis(carboxymethyl)ethylenediamine $]-[9,10,16$, 
17,23,24-hexacarboxyphthalocyaninatozinc(II)-2,3-dicarboxylato]platinum(II) hexasodium salt, Pc'ZnPtEDDA (2a). Synthesis was carried out by the method reported earlie ${ }^{[5]}$ using solution of the Pc'Zn $(180 \mathrm{mg}, 0.16 \mathrm{mmol})$ in distilled water $(75 \mathrm{ml})$ and solution of the $\left[\mathrm{PtEDDA}\left(\mathrm{NO}_{3}\right)(\mathrm{OH})\right](140 \mathrm{mg}, 0.31 \mathrm{mmol})$ in distilled water (75 ml). Yield: $80 \mathrm{mg}(60 \%)$. Found: C 38.95, H 2.04, N $10.02 \%$. $\mathrm{C}_{46} \mathrm{H}_{20} \mathrm{~N}_{10} \mathrm{O}_{20} \mathrm{ZnPt} \mathrm{Na}$ requires C 38.61, H 1.41, N 9.79. IR (KBr) $v_{\max } \mathrm{cm}^{-1}: 1450.6,1488.2,1563.4,1631.1,1649.9,1702.5$. UV-vis (DMSO) $\lambda_{\max } \mathrm{nm}: 362,698$

b) $\left[k N^{2}-N, N^{\prime}-\right.$ bis (carboxymethyl)ethylenediamine]- $\mu-[16(9)$, 17(10), 23,24-tetracarboxyphthalocyaninatozinc(II)-2, 3, 9(16),10(17)-tetracarboxylato]diplatinum(II) tetrasodium salt, $P c^{\prime} \mathrm{Zn}(\mathrm{PtEDDA})_{2}(\mathbf{2 b})$. The same procedure was used as for complex 2a but using the solutions of [PtEDDA $\left.\left(\mathrm{NO}_{3}\right)(\mathrm{OH})\right](130 \mathrm{mg}, 0.29$ $\mathrm{mmol})$ in distilled water $(15 \mathrm{ml})$ and of Pc'Zn $(78 \mathrm{mg}, 0.07 \mathrm{mmol})$ in distilled water $(30 \mathrm{ml})$. Yield: $75.2 \mathrm{mg}(61 \%)$. Found: C 35.95, $\mathrm{H} 2.14, \mathrm{~N} 10.12 \% . \mathrm{C}_{52} \mathrm{H}_{32} \mathrm{~N}_{12} \mathrm{O}_{24} \mathrm{ZnPt}_{2} \mathrm{Na}_{4}$ requires $\mathrm{C} 35.56, \mathrm{H} 1.84$, N 9.57. IR (KBr) $v_{\text {max }} \mathrm{cm}^{-1}$ : 1446.8, 1492.0, 1570.9, 1627.3, 1706.3. UV-vis (DMSO) $\lambda_{\max }^{\max } \mathrm{nm:} \mathrm{358,698.}$

c) tris $\left[k N^{2}-N, N^{\prime}\right.$-bis(carboxymethyl)ethylenediamine $]-\mu^{3}-[23$, 24-dicarboxyphthalocyaninatozinc(II)-2, 3, 9, 10,16, 17-hexacarboxylato]triplatinum(II) disodium salt, $\operatorname{Pc} Z \operatorname{Zn}(\operatorname{PtEDDA})_{3}$ (2c). The same procedure was used as for complex 2a but using the solutions of [PtEDDA $\left.\left(\mathrm{NO}_{3}\right)(\mathrm{OH})\right](65 \mathrm{mg}, 0.145 \mathrm{mmol})$ in distilled water $(30 \mathrm{ml})$ and of $\mathrm{Pc}^{\prime} \mathrm{Zn}(23.2 \mathrm{mg}, 0.021 \mathrm{mmol})$ in distilled water (30 ml). Yield: $26.2 \mathrm{mg}$ (60 \%). Found: C 33.13, H 2.38, N 9.81\%. $\mathrm{C}_{58} \mathrm{H}_{44} \mathrm{~N}_{14} \mathrm{O}_{28} \mathrm{ZnPt}_{3} \mathrm{Na}_{2}$ requires $\mathrm{C} 33.47, \mathrm{H} \mathrm{1.84,} \mathrm{N} \mathrm{9.57.} \mathrm{IR} \mathrm{(KBr)}$ $v_{\max } \mathrm{cm}^{-1}: 1446.8,1488.2,1574.7,1623.3,1710.0$. UV-vis (DMSO) $\lambda_{\max }^{\max } \mathrm{nm}: 361,696$.

d) tetrakis $\left[k N^{2}-N, N^{\prime}\right.$-bis(carboxymethyl)ethylenediamine]- $\mu^{4}$ [phthalocyaninatozinc(II)-2,3,9,10,16,17,23,24-octacarboxylato] tetraplatinum(II), $P c^{\prime} \mathrm{Zn}(\mathrm{PtEDDA})_{4}(\mathbf{2 d})$. The same procedure was used as for complex 2a but using the solutions of [PtEDDA $\left(\mathrm{NO}_{3}\right)$ $(\mathrm{OH})](184 \mathrm{mg}, 0.41 \mathrm{mmol})$ in distilled water $(30 \mathrm{ml})$ and of $\mathrm{Pc}^{\prime} \mathrm{Zn}$ $(50 \mathrm{mg}, 0.045 \mathrm{mmol})$ in distilled water $(30 \mathrm{ml})$. Yield: $62.82 \mathrm{mg}$ (58 \%). Found: C 32.41, H 3.17, N $8.81 \%$. $\mathrm{C}_{64} \mathrm{H}_{56} \mathrm{~N}_{16} \mathrm{O}_{32} \mathrm{ZnPt}_{4}$ requires C 31.94, H 2.35, N 9.31. IR (KBr) $v_{\max } \mathrm{cm}^{-1}: 1446.8,1488.2$, 1570.9, 1622.0, 1702.3. UV-vis (DMSO) $\lambda_{\max }^{\max } \mathrm{nm:360,698.}$

\section{Methods}

IR spectra were recorded on an FSM-1201 FT spectrometer with $\mathrm{KBr}$ pellets. Electronic absorption spectra were recorded with Hewlett Packard 8453 and Shimadzu UV-2550 spectrophotometers, while fluorescence excitation and emission spectra were measured on a Varian Eclipse spectrofluorimeter. The monochromatic light intensity was measured with a calibrated Si photodiode (Thorlabs).

Fluorescence quantum yields $\left(\Phi_{\mathrm{F}}\right)$ were determined in air saturated DMSO using the comparative method according to relationship (1):

$$
\Phi_{F}=\Phi_{F}^{r e f} \frac{F A^{r e f}\left(n_{D}\right)^{2}}{F^{r e f} A\left(n_{D}^{r e f}\right)^{2}}
$$

where $F$ and $F^{\text {ref }}$ are the areas under the fluorescence curves, $A$ and $A^{\text {ref }}$ are the respective absorbances at the excitation wavelength (the same in our experiments), $\mathrm{n}_{D}$ and $\mathrm{n}_{D}$ ref are the refractive indexes of the solvents used for the sample and reference, respectively. PcZn in DMSO was used as a reference $\left(\Phi_{F}^{r e f}=0.20^{[9]}\right)$ at an excitation wavelength of $700 \mathrm{~nm}$.

Fluorescence lifetimes were measured using a time correlated single photon counting setup (TCSPC) (FluoTime 200, Picoquant $\mathrm{GmbH}$ ) with a diode laser (LDH-P-670 with PDL 800-B, Picoquant $\mathrm{GmbH}, 670 \mathrm{~nm}, 20 \mathrm{MHz}$ repetition rate, 44 ps pulse width). Fluorescence was detected under the magic angle with a peltier cooled photomultiplier tube (PMT) (PMA-C 192-N-M, Picoquant) and integrated electronics (PicoHarp 300E, Picoquant GmbH). A monochromator with a spectral width of about $4 \mathrm{~nm}$ was used to select the required emission wavelength band. The response function of the system, which was measured with a scattering Ludox solution (DuPont), had a full width at half-maximum (FWHM) of 300 ps. All luminescence decay curves were measured at the maximum of the emission peak and lifetimes were obtained by deconvolution of the decay curves using the FluoFit Software program (PicoQuant $\mathrm{GmbH}$, Germany). The support plane approach ${ }^{[10]}$ was used to estimate the errors of the decay times.

Triplet decay kinetics was recorded in deoxygenated DMSO (bubbling with argon for $15 \mathrm{~min}$ ) on a laser flash photolysis system described below. The excitation pulses were produced by a QuantaRay Nd: YAG laser providing $400 \mathrm{~mJ}, 9 \mathrm{~ns}$ pulses of laser light at $10 \mathrm{~Hz}$, pumping a Lambda-Physic FL 3002, dye (Pyridin 1 in methanol). The analyzing beam source was from a Thermo Oriel xenon arc lamp, and a photomultiplier tube was used as a detector. Signals were recorded with a two-channel $300 \mathrm{MHz}$ digital real-time oscilloscope (Tektronix TDS 3032C); kinetic curves were averaged over 256 laser pulses. The triplet lifetimes were determined by exponential fitting of the kinetic curves using the OriginPro 7.1.

The photodegradation quantum yield $\left(\Phi_{\mathrm{p}}\right)$ estimations were carried out in DMSO. The concentration of the conjugates was about $5 \mu \mathrm{M}$. Solutions were irradiated with a light emitting diode IS-2-693 (ZAO "TECHNOEKSAN", Russia), which provided a flux $1.1 \cdot 10^{17}$ photons $\cdot \mathrm{s}^{-1} \cdot \mathrm{cm}^{-2}$ at the sample surface in the of $688-698$ $\mathrm{nm}$ region. The decrease of the Pc absorbance $(A)$ was measured at the $Q$ band maximum as a function of irradiation time. The quantum yields $\Phi_{\mathrm{p}}$ were calculated from the initial part of the $A(\mathrm{t})$ dependence curves according to Equation 2:

$$
\Phi_{P}=\frac{V}{I_{a b s} l \varepsilon} \frac{d A}{d t}
$$

where $V$ is the reaction volume, $I_{a b s}$ is the absorption of intensity of incident light by the sample (einsteins per second), $l$ is the optical path length, and $\varepsilon$ - decimal molar absorption coefficient at the maximum of the absorption band. The term $d A / d t$ was determined graphically.

The quantum yields of photodegradation were estimated with about $15 \%$ accuracy.

The singlet oxygen quantum yield, $\Phi_{\Delta}$, of the conjugates in DMSO solution was estimated based on the literature procedures by using PcZn as a reference and DPBF as a hydrophobic ${ }^{1} \mathrm{O}_{2}$ trap. ${ }^{[11]}$ The concentration of DPBF was lowered to $\sim 3 \cdot 10^{-5} \mathrm{M}$ to inhibit chain reactions induced by DPBF in the presence of singlet oxygen. ${ }^{[11]}$ A xenon lamp $(150 \mathrm{~W})$ was used as a light source. The excitation light first passed through a yellow glass filter GS-18 and water filter to cut off ultraviolet and infrared radiation and then through an interference filter with a transmission maximum at 680 and a $\pm 25 \mathrm{~nm}$ bandpass. The light intensity at the sample surface was $2.4 \cdot 10^{15}$ photons $\cdot \mathrm{s}^{-1} \cdot \mathrm{cm}^{-2}$. The values of $\Phi_{\Delta}$ were calculated using the Equation (3).

$$
\Phi_{\Delta}=\Phi_{\Delta}^{r e f} \frac{W I_{a b s}^{r e f}}{W^{r e f} I_{a b s}}
$$

where $\Phi_{\Delta}^{\text {ref }}$ is the singlet oxygen quantum yield for the PcZn reference compound $\left(\Phi_{\Delta}\right.$ of PcZn in DMSO $\left.=0.67^{[12]}\right)$; and $W$ and $W^{\text {ref }}$ are the DPBF photobleaching rates in the presence of conjugate under investigation and PcZn, respectively. $\mathrm{I}_{\mathrm{abs}}$ and $\mathrm{I}_{\mathrm{abs}}$ ref are the intensities of light absorption by the conjugate and PcZn, respectively. Identical initial DPBF concentrations were used for the PcZn reference compound and the samples. The accuracy of $\Phi_{\Delta}$ estimation was about $10 \%$.

All of the experiments were carried out at ambient temperature. 


\section{Biological Studies}

Human laryngeal cancer cell line (HEp2) and human lung adenocarcinoma (A549) cells were grown $\left(37^{\circ} \mathrm{C}, 5 \% \mathrm{CO}_{2}\right)$ in Eagle's minimum essential medium with phenol red and supplemented with $8-10 \%$ fetal calf serum (FCS), $2 \mathrm{mM} L$-glutamine (Scientific and production enterprise (NPP) "Paneko", Russia). The cell lines were provided by D.I. Ivanovsky Institute of Virology of Russian Academy of Medical Sciences.

Cells were plated at a density of $0.7 \cdot 10^{4}$ cells/well in 96 -well flat-bottom microplate ("Costar", USA) and incubated overnight. Then Pc under test was introduced at concentration from 6.2 to 500 $\mu \mathrm{g} / \mathrm{ml}$, and after $2 \mathrm{~h}$ incubation cells were exposed to a light dose of $10 \mathrm{~J} / \mathrm{cm}^{2}, 16.7-17.0 \mathrm{~mW} / \mathrm{cm}^{2}$ with a $500 \mathrm{~W}$ halogen lamp equipped with a cut-off KS-10 filter to bar wavelengths shorter than $620 \mathrm{~nm}$. In parallel, non-irradiated cells were used to study dark cytotoxicity. Following treatment, cells were incubated for an additional $24 \mathrm{~h}$ period and cell viability was determined by means of MTT assay.

\section{Results and Discussion}

\section{Synthesis}

Ammine complexes of CCs of $\mathrm{Pt}^{\mathrm{II}}$ and octacarboxysubstituted PcZn 1a-d were synthesized from the sodium salt of zinc 2,3,9,10,16,17,23,24-octacarboxyphthalocyanine (Pc'Zn) and cis-diamminedichloroplatinum(II) (cisplatin, cis$\left.\operatorname{Pt}\left(\mathrm{NH}_{3}\right)_{2} \mathrm{Cl}_{2}\right)$ using method analogous to that reported before. ${ }^{[4]}$ Complexes with two and three ammine platinum fragments have been synthesized for the first time. New EDDA containing complexes of CCs of $\mathrm{Pt}^{\mathrm{II}}$ and octacarboxy-substituted $\mathrm{PcZn}$ 2a-d were synthesized using three-stage method analogous to $^{[5]}$ (Scheme 1). The number of platinum atoms in each case was controlled by the stoichiometry of starting materials and was confirmed by elemental analysis data.

The IR spectra of the products differ from those of the initial salt spectrum in the $1400-1700 \mathrm{~cm}^{-1}$ region. Spectra of compounds 2a-d (Figure 1) closely resemble the IR spectra of EDDA containing CCs of platinum(II) and octacarboxysubstituted $\mathrm{PcCo}^{\mathrm{II}}$ which have been reported previously ${ }^{[5]}$. It is known that the IR spectra of the compounds containing chelate rings with the metal atoms involved demonstrate two bands in the $1500-1560 \mathrm{~cm}^{-1}$ region ${ }^{[13]}$. The $\mathrm{C}=\mathrm{O}$ vibrations of carboxyl groups covalently bonded to platinum(II) usually exhibit two or three bands between $1600-1708 \mathrm{~cm}^{-1} \cdot{ }^{[14-16]}$ So, the bands which lie at $c a$. 1560, 1570, 1620-1650 and 1700 $\mathrm{cm}^{-1}$ in the spectra of $\mathbf{1} \mathbf{a}-\mathbf{d}$ and $\mathbf{2} \mathbf{a}-\mathbf{d}$ can be readily assigned to these vibrations.

\section{Ground State Properties}

Synthesized ammine and diamine platinum(II) conjugates are soluble in DMSO and DMF. In DMSO, conjugates and the unconjugated $\mathrm{Pc}^{\prime} \mathrm{Zn}$ have similar electronic absorption spectra with $Q$ band maxima at 696-698 nm and molar extinction coefficients of between $175000-195000 \mathrm{M}^{-1} \cdot \mathrm{cm}^{-1}$ (Table 1). ${ }^{[17]}$<smiles>O=C(O)CNCCNCC(=O)O</smiles>

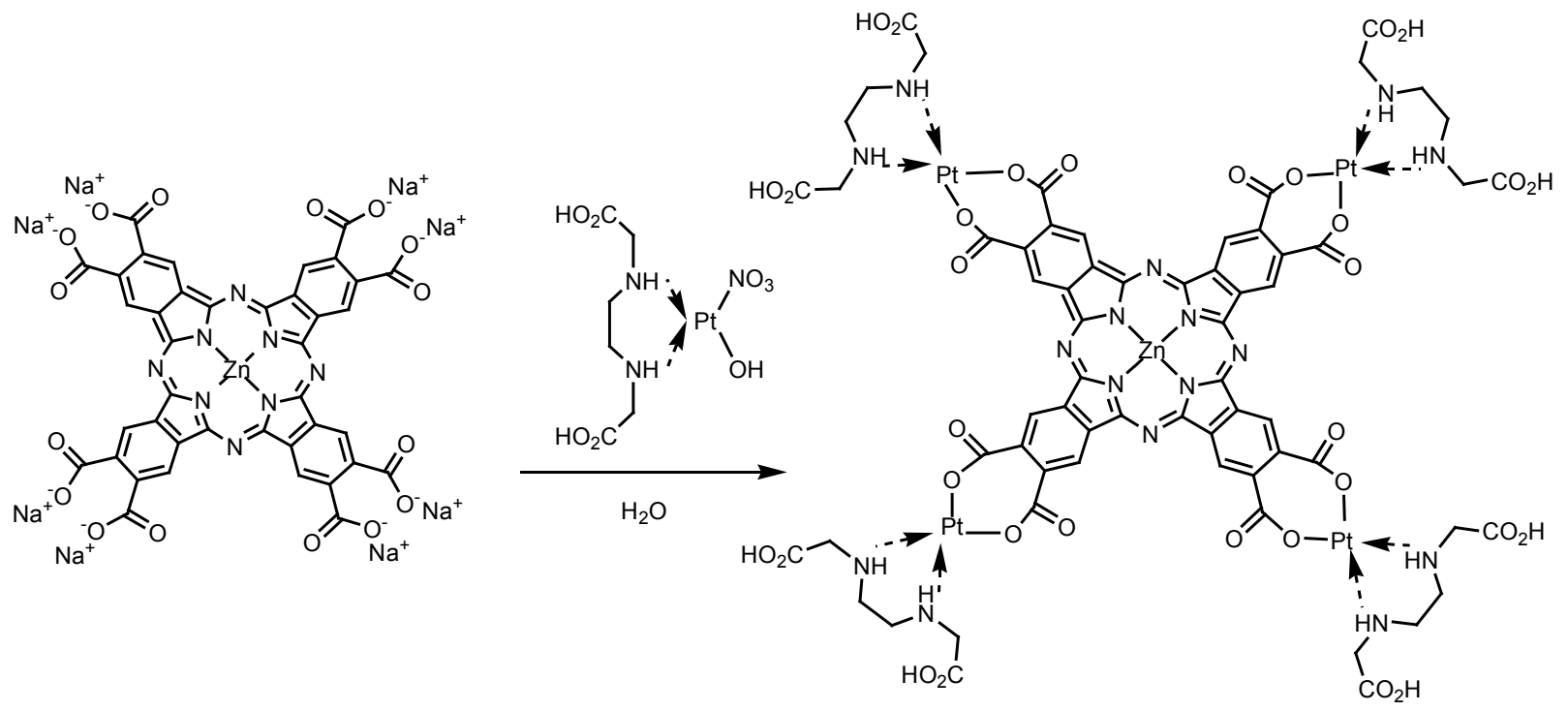

Scheme 1. Synthetic route for the produced diamine complexes of CC of platinum(II) with octacarboxy-substituted zinc phthalocyanine (2a-d), illustrated by the complex 2d, tetrakis[k $N^{2}-N, N^{\prime}$-bis(carboxymethyl)ethylenediamine]- $\mu^{4}$-[phthalocyaninatozinc(II)2,3,9,10,16,17,23,24-octacarboxylato]tetraplatinum(II), Pc'Zn(PtEDDA) . 


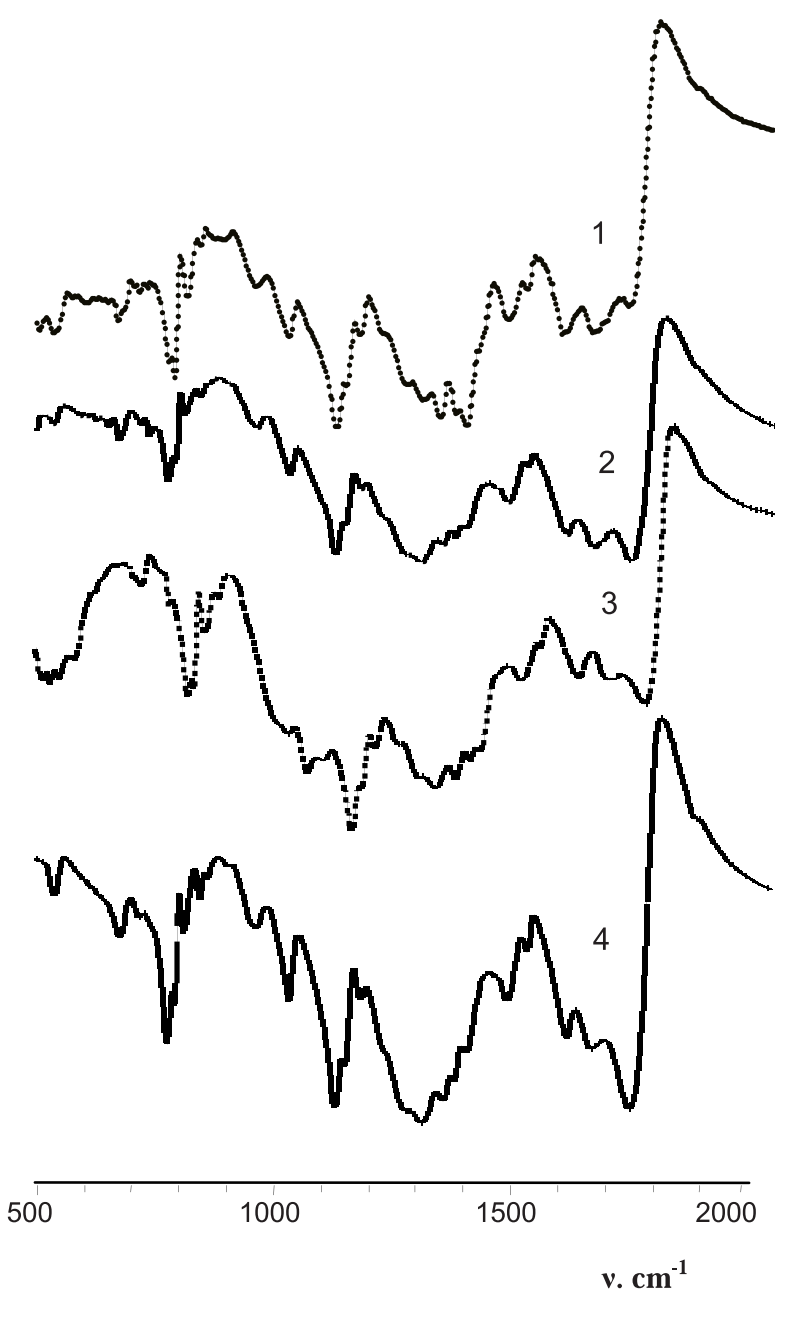

Figure 1. IR spectra of $\mathbf{2 a}(1), \mathbf{2 b}(2) \mathbf{2 c}$ (3) and $\mathbf{2 d}$ (4).
With the exception of fully complexed 1d, freshlyprepared conjugates are soluble in water. After long storage on air or drying, however, the solubility of CCs in water slows down significantly. The solubility in aqueous media of conjugates with diamine platinum is higher than that for their ammine counterparts. Thus, electronic absorption spectrum of $\mathbf{2 a}$ in water has typical for monomers narrow $Q$ band, while distinct absorption of dimer at $650 \mathrm{~nm}$ evidences the partial aggregation in aqueous solution of 1a conjugate (Figure 3). In general, solubility of conjugates in aqueous solutions significantly decreases as the number of platinum atoms increases. The $Q$ band broadening and appearance of noticeable absorption at 650 $\mathrm{nm}$ is consistent with aggregate formation (Figure 2). The degree of aggregation increases along with the number of platinum atoms in the molecule. Since the aggregates are photochemically inactive, investigations of the optical and photochemical properties of the CCs were carried out in DMSO. The stability of CCs in DMSO was confirmed by IR spectroscopy of dried product.

\section{Excited Singlet and Triplet State Properties}

The fluorescence behavior of the conjugates was studied in DMSO. Figure 4 shows the absorption, fluorescence emission and excitation spectra for 1a as an example. The shape of the excitation spectra of studied compounds is similar to the absorption spectra, and exhibits approximate mirror symmetry with the emission spectrum. The proximity of the wavelength of the $Q$ band absorption to the $Q$ band maximum of the excitation spectrum for conjugates suggests that the nuclear configurations of the ground and excited states are similar and not affected by excitation. There is a

Table 1. Photophysical and photochemical parameters for the covalent conjugates of ammine and diamine platinum(II) and octacarboxy substituted zinc phthalocyanine in DMSO.

\begin{tabular}{ccccccccc}
\hline Compound & $\lambda_{\text {abs }}{ }^{m a x}, \mathrm{~nm}$ & $\varepsilon, \mathrm{M}^{-1} \cdot \mathrm{cm}^{-1}$ & $\lambda_{\mathrm{F}}^{\max }, \mathrm{nm}$ & $\tau_{\mathrm{F}}, \mathrm{ns}$ & $\Phi_{\mathrm{F}}$ & $\tau_{\mathrm{T}}, \mu \mathrm{s}$ & $\Phi_{\Delta}$ & $\Phi_{\mathrm{P}} \cdot 10^{6}$ \\
\hline Pc'Zn & 698 & 190000 & $708^{[17]}$ & - & $0.24^{[17]}$ & $480^{[17]}$ & 0.56 & 1.8 \\
1a & 697 & 180000 & 714 & 3.3 & 0.19 & 320 & 0.54 & 2.8 \\
1b & 698 & 180000 & 712 & 3.5 & 0.18 & 370 & 0.58 & 2.4 \\
1c & 698 & 180000 & 712 & 3.2 & 0.14 & 250 & 0.47 & 2.5 \\
1d & 696 & 175000 & 714 & 3.2 & 0.16 & 330 & 0.55 & 1.4 \\
2a & 698 & 190000 & 712 & 4,3 & 0.17 & 430 & 0.60 & 2.4 \\
2b & 698 & 185000 & 714 & 3,9 & 0.19 & 420 & 0.57 & 2.3 \\
2c & 698 & 190000 & 711 & 4,3 & 0.18 & 450 & 0.54 & 2.5 \\
2d & 698 & 195000 & - & - & 0.18 & - & 0.41 & 1.9 \\
\hline
\end{tabular}

The narrow $Q$ bands of conjugates and the similarity of the vibrational envelope to that of Pc'Zn provide evidence for an absence of aggregation (spectrum for 1d in DMSO is exemplified in Figure 2). This suggests that ammine and diamine platinum coordination has only a minor effect on the electronic structure of octacarboxy-substituted zinc phthalocyanine. This is not unexpected based on what is known about the frontier MOs of the Pc $\pi$-system. The $1 a_{1 \mathrm{u}}$ HOMO and $1 e_{\mathrm{g}}^{*} \mathrm{LUMO}$ of PcZn have very small MO coefficients at the peripheral $\beta$-positions of the fused benzene rings. ${ }^{[1]}$
Stokes shift of 14-18 nm for 1a-d and 13-16 nm for 2a-d series. The fluorescence quantum yields $\left(\Phi_{\mathrm{F}}\right)$ in DMSO solutions are consistent with those reported previously for aqua platinum conjugates; ${ }^{[1]}$ decrease from 0.24 for the parent Pc'Zn to between 0.14-0.19 for the conjugates 1a-d and 2a-c was observed (Table 1). Lower $\Phi_{F}$ values are expected for platinum-containing compounds due to spinorbit coupling, since the heavy atom effect introduced by the Pt atoms enhances the rate of intersystem crossing to the $\mathrm{T}_{1}$ state and hence reduces the fluorescence intensity. The 


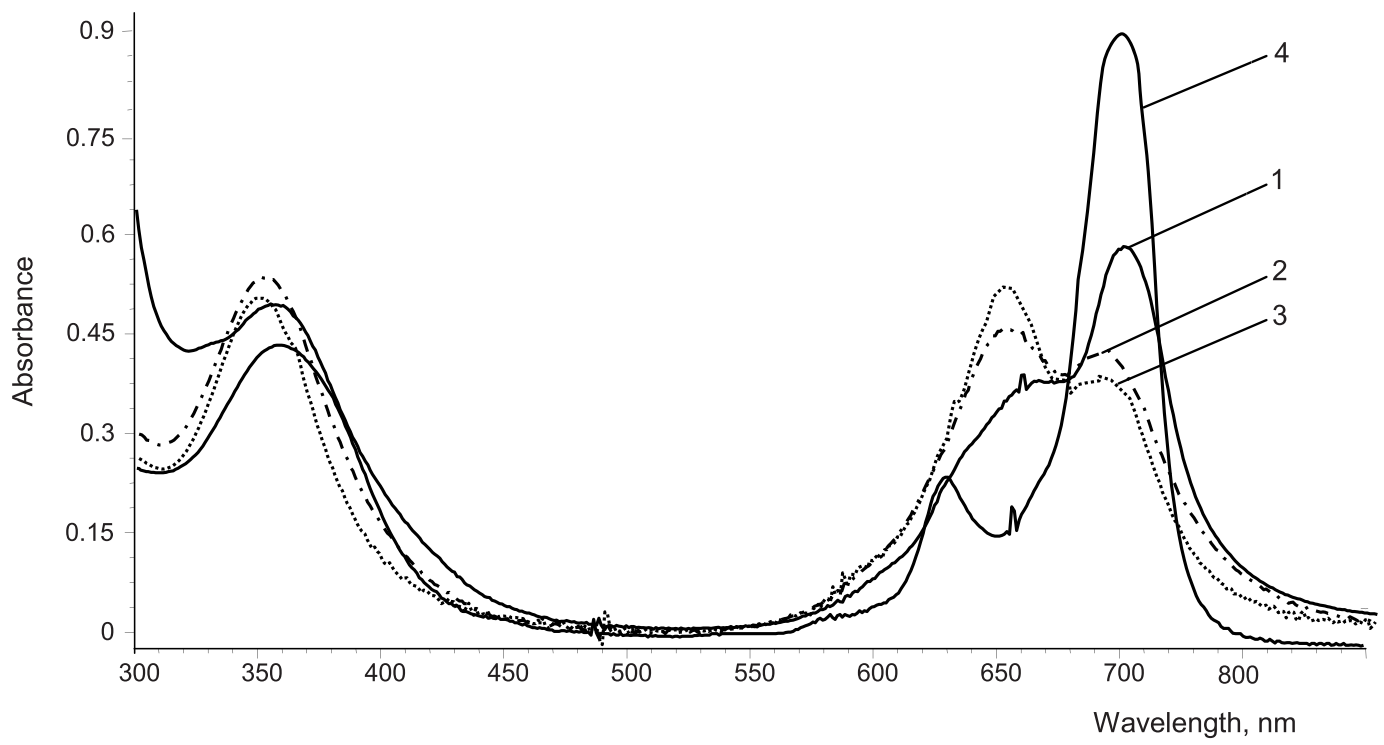

Figure 2. UV-visible spectra of 1a-c (1-3, correspondingly) in $\mathrm{H}_{2} \mathrm{O}$ and of $\mathbf{1 d}$ in DMSO (4). Concentration $0.5 \cdot 10^{-5} \mathrm{M}$.

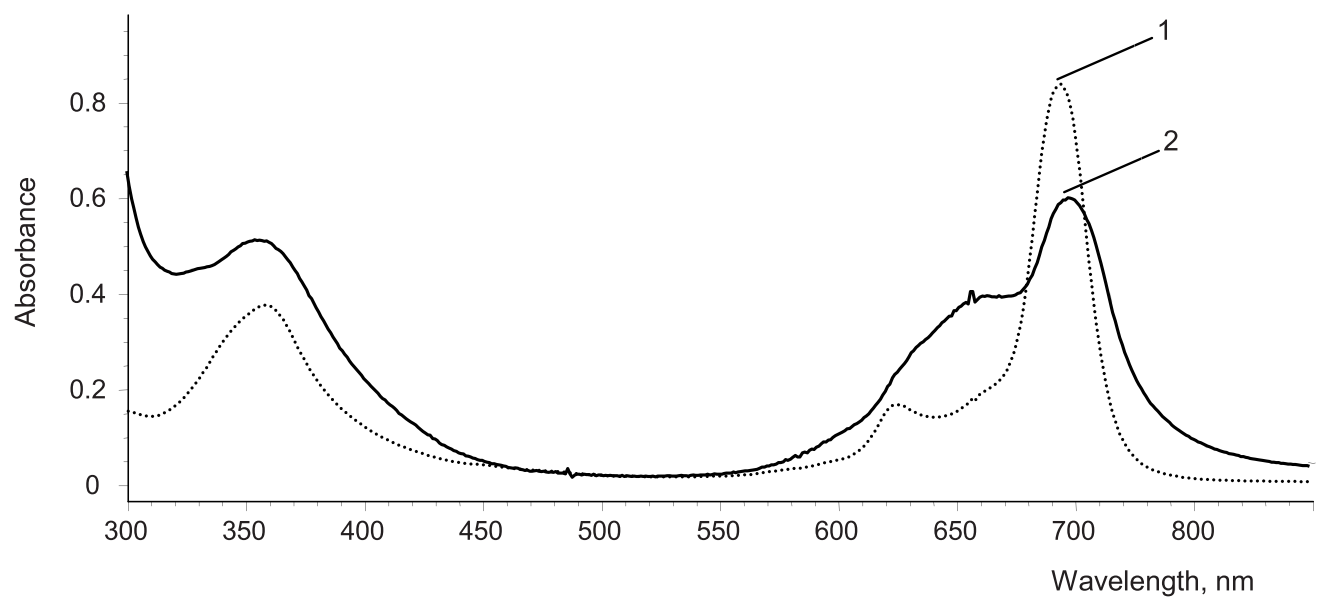

Figure 3. UV-visible spectra of $\mathbf{2 a}(1)$ and $\mathbf{1 a}(2)$ in $\mathrm{H}_{2} \mathrm{O}$.

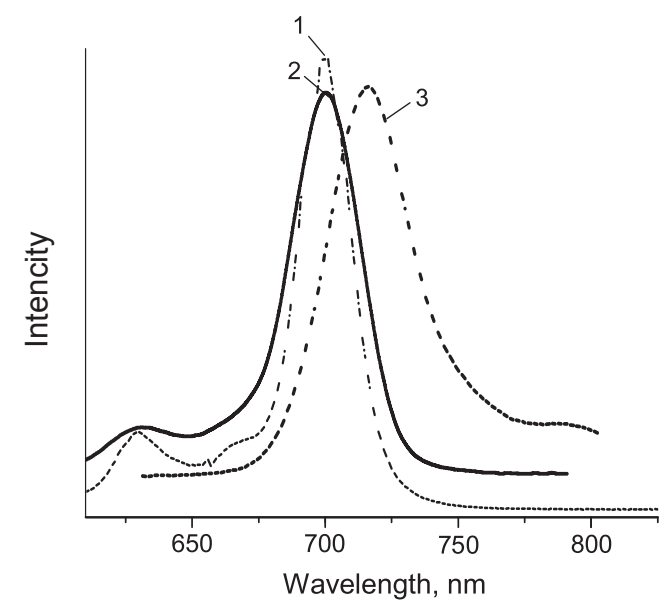

Figure 4. Absorption (1), excitation (2) and fluorescence emission (3) spectra for 1a in DMSO.

fluorescence emission properties were complemented by the fluorescence lifetimes. The fluorescence lifetimes $\left(\tau_{\mathrm{F}}\right)$ for 1a-d are of between 3.2-3.5 ns (Table 1) while those of diamine platinum(II) conjugates 2a-d are higher (3.9-4.3 ns).
The introduction of Pt atoms on the Pc'Zn periphery has only a limited effect on the dynamics of the $S_{1}$ state.

On the whole, it can, therefore, be concluded that the singlet excited state parameters of the ammine and diamine platinum(II) conjugates in DMSO are very similar.

A positive feature of the ammine and diamine platinum(II) conjugates is their high excited triplet state lifetimes. Compounds 1a-d have triplet lifetimes $\left(\tau_{\mathrm{T}}\right)$ of between 250-370 $\mu$ s in deoxygenated DMSO (Table 1). These values are lower than that of the unconjugated Pc'Zn, $480 \mu \mathrm{s}$. The $\tau_{\mathrm{T}}$ lifetimes of the $\mathbf{2 a - c}$ are higher, $420-450 \mu$ s, however still lower than $\tau_{\mathrm{T}}$ of Pc'Zn. Lower triplet lifetime values are expected for conjugates with platinum moieties, since the heavy atom effect introduced by the Pt atoms enhances the rate of intersystem crossing from the $T_{1}$ excited state to the ground state. Still $\tau_{\mathrm{T}}$ values are sufficiently high to provide efficient sensitization of singlet oxygen production.

\section{Singlet Oxygen Quantum Yields}

The quantum yields of singlet oxygen formation $\left(\Phi_{\Delta}\right)$, were studied using a DPBF chemical trapping method in 


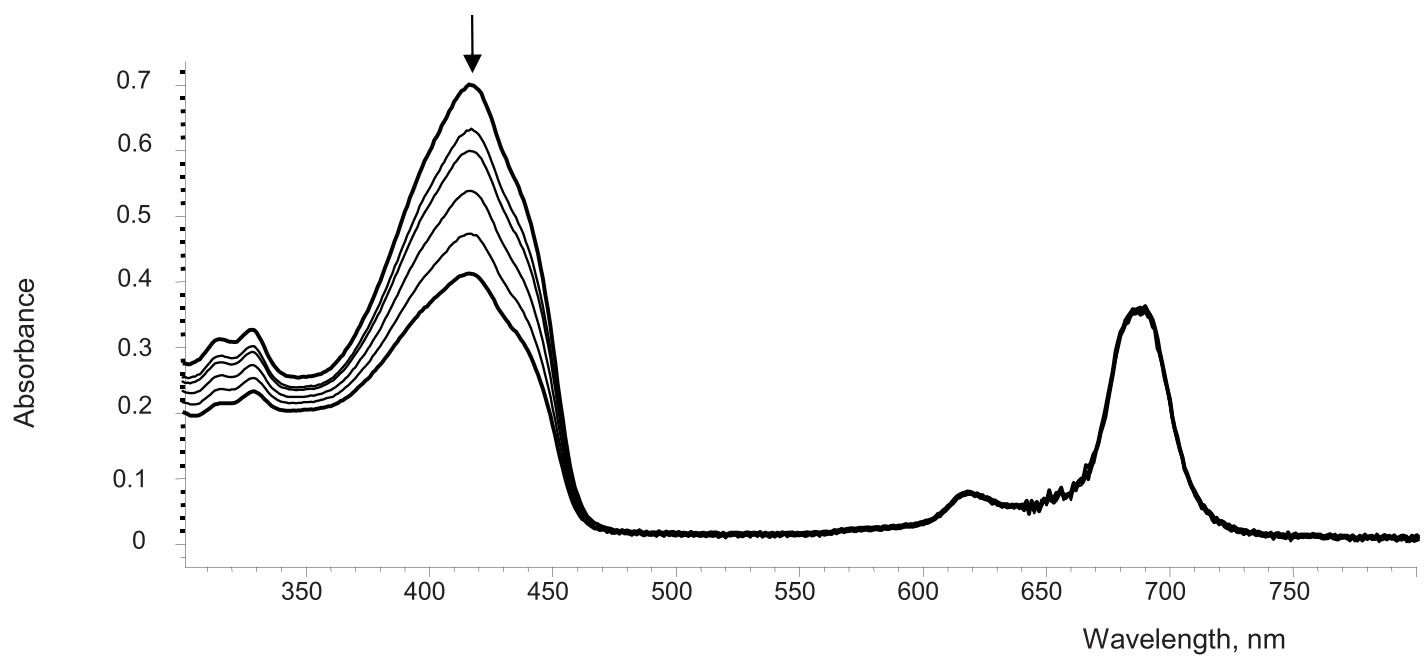

Figure 5. The change of absorption spectrum upon irradiation time for air saturated DMSO solution of $5 \mu \mathrm{M}$ DPBF and $2 \mu \mathrm{M} 1 \mathrm{a}$. Excitation at $Q$ band with filtered light of xenon lamp $(150 \mathrm{~W})$.

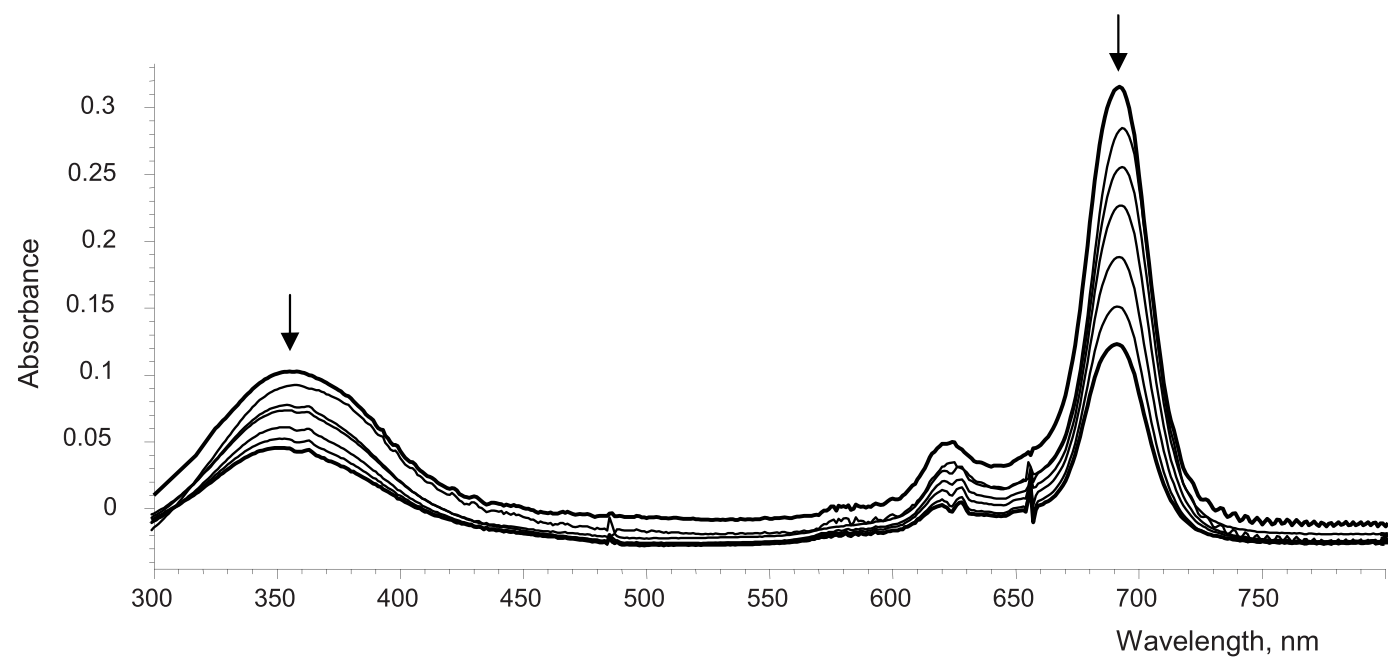

Figure 6. Spectral changes for $1 \mathrm{c}$ in air-saturated DMSO under excitation at $Q$ band at $30 \mathrm{~min}$ intervals ( $\lambda_{\text {ex }} 693 \mathrm{~nm}$, light emitting diode).

DMSO. The selective excitation of conjugates in the $Q$ absorption band resulted in disappearance of DPBF (Figure 5). There were no changes in the $Q$ band intensities during the $\Phi_{\Delta}$ determinations, confirming that conjugates are not degraded during singlet oxygen studies. The $\Phi_{\Delta}$ values are summarized in Table 1. For 1a-d, the $\Phi_{\Delta}$ values are in the range 0.47-0.58, close to that for parent Pc'Zn, and show no relationship on the number of platinum atoms. The $\Phi_{\Delta}$ values for $\mathbf{2 a - d}$ compounds tend to reduce with increase of $\mathrm{Pt}$ in molecule from 0.60 for 2a to 0.41 for $\mathbf{2 d}$. However these variations are small enough and in whole it may be concluded that the number of platinum atoms has only a minor effect on the singlet oxygen yields. Conjugates of Pc'Zn with ammine and diamine platinum(II) possess high singlet oxygen quantum yields and therefore show potential as sensitizers for PDT.

\section{Photodegradation Studies}

The spectral changes observed in air-saturated DMSO solutions of conjugates during irradiation are shown in Figure 6 (using $1 \mathbf{c}$ as an example). Kinetic of dye photodegradation was recorded under excitation with light of 688-698 nm. Under these conditions "dark" degradation was negligible. It was observed (Figure 6) that during illumination, photobleaching of the absorption maxima occurred without appearance of new absorption maxima. This indicates that degradation of the Pc chromophore produces fragments, which do not absorb in the visible region. The photobleaching kinetics follows the first-order law and can be well fitted by a single-exponential decay function. Based on data reported previously ${ }^{[17,18]}$ it may be assumed that there is oxidative photodegradation of the phthalocyanine ring. The most probable products of phthalocyanine photobleaching are known to be phthalimides. ${ }^{[19,20]}$

The 1a-d, 2a-d conjugates and Pc'Zn showed about the same photostability with photodegradation quantum yields $\Phi_{\mathrm{P}}$ in the (1.4-2.8) $10^{-6}$ range (Table 1). These values show that the compounds under investigation are of high photostability in air-saturated DMSO solution under $Q$ band excitation. The $\Phi_{\mathrm{p}}$ yields obtained in this study are very close to reported previously for conjugates of aqua platinum (II) and octacarboxy substituted zinc phthalocyanine. ${ }^{[1]}$ This 
Table 2. Dark cytotoxicity and photocytotoxicity of phthalocyanines 2a and Pc'Zn.

\begin{tabular}{ccccc}
\hline \multirow{2}{*}{ Compound } & \multicolumn{2}{c}{ Photocytotoxicity $\mathrm{IC}_{50}, \mu \mathrm{M}$} & \multicolumn{2}{c}{ Dark cytotoxicity $\mathrm{IC}_{50}, \mu \mathrm{M}$} \\
\cline { 2 - 5 } & $\mathrm{HEp} 2$ & $\mathrm{~A} 549$ & HEp2 & $\mathrm{A549}$ \\
\hline Pc'Zn & $205.8 \pm 2.6$ & $221.8 \pm 2.9$ & $433.3 \pm 3.1$ & $>>450$ \\
2a & $103.8 \pm 2.2$ & $185.6 \pm 2.7$ & $301.5 \pm 2.7$ & $278.5 \pm 3.2$ \\
\hline
\end{tabular}

means that platinum moieties have only a limited effect on the photostability of conjugates.

\section{The Biological Effect Studies in vivo}

The biological effect of conjugates was preliminary examined using human laryngeal cancer cell line (HEp2) and lung adenocarcinoma (A549) cells with monoconjugate 2a as the most water-soluble and suitable for clinical administration among compounds under investigation. The effect of different concentrations of $\mathbf{2 a}$ on cell survival was evaluated in the dark and upon exposure to a light dose of $10 \mathrm{~J} / \mathrm{cm}^{2} \mathrm{~m}$. The same experiments for comparison were performed with parent octacarboxy-substituted Pc'Zn. When cells were treated with phthalocyanines $\mathbf{2 a}$ and Pc'Zn, cell viability diminished in a concentration-dependent manner, the obtained $\mathrm{IC}_{50}$ values (concentration corresponding to $50 \%$ inhibition of cell proliferation) are summarized in Table 2. As shown in Table 2, the $\mathrm{IC}_{50}$ doses of $\mathbf{2} \mathbf{a}$ are lower than those of Pc'Zn both in dark and under illumination, evidencing enhancement of phthalocyanine dark and photocytotoxicity with introduction of $\mathrm{Pt}$ atoms in the molecule.

\section{Conclusions}

Covalent conjugates of ammine and diamine platinum(II) and octacarboxy substituted PcZn, bearing one, two, three and four platinum fragments have been synthesized and characterized by elemental analysis, and IR and UV-visible spectroscopy. All studied conjugates have good solubility in DMF and DMSO without aggregation. With the exception of fully complexed 1d, freshly-prepared conjugates are soluble in water. The solubility in aqueous media of conjugates with diamine platinum is higher than that for their ammine counterparts. The $Q$ band broadening and appearance of noticeable absorption at $650 \mathrm{~nm}$ in aqueous solution is consistent with aggregate formation in solutions of all conjugates except of $\mathbf{2 a}$. The degree of aggregation increases along with the number of platinum atoms in the molecule.

The photophysical and photochemical properties of conjugates were investigated in DMSO. The stepwise ammine or diamine platinum coordination has only a limited effect on the electronic structure, excited singlet and triplet state parameters of octacarboxy substituted zinc phthalocyanine. Similar trend is observed in the quantum yields of singlet oxygen generation. The conjugates have high photostabilities in aerated DMSO. The photobleaching quantum yields are in the $1.4-2.8 \cdot 10^{-6}$ range even after the addition of the heavy platinum atoms. The conjugates efficiently sensitize singlet oxygen formation. Preliminary experiments have shown that their activity in photoinactivation of cancer cells and dark cytotoxicity are some higher, than those of parent octacarboxy substituted PcZn. Thus, the covalent conjugates of ammine and diamine platinum(II) and octacarboxy substituted PcZn show potential as dual action anticancer drugs.

Acknowledgements. This work was supported by the Russian Foundation for Basic Research (Project No. 11-0393960 UARa), by the Department of Science and Technology (DST) and the National Research Foundation (NRF) of South Africa through DST/NRF South African Research Chairs Initiative for Professors of Medicinal Chemistry and Nanotechnology, and by Rhodes University.

\section{References}

1. Bulgakov R.A., Kuznetsova N.A., Dolotova O.V., Solovieva L.I., Mack J., Chidawanyika W., Kaliya O.L., Nyokong T. J. Porphyrins Phthalocyanines 2012, 16, 1217-1224.

2. Brunner H., Obermeier H. Angew. Chem. 1994, 106, 2305-2306.

3. Nemykin V., Mytsyk V., Volkov S., Kobayashi N. J. Porphyrins Phthalocyanines 2000, 4, 551-554.

4. Mytsyk V.M., Nemykin V.N., Volkov S.V. Ukr. Khim. Zh. (Russ. Ed.) 2003, 69, 3-8.

5. Dolotova O.V., Kaliya O.L. J. Porphyrins Phthalocyanines 2011, 15, 632-638.

6. Pat. RF 2193563, 2000.

7. Solov'eva L.I., Yuzhakova O.A., Kaliya O.L., Luk'yanets E.A. Russ. J. Gen. Chem. 2002, 72, 300-306.

8. Pat. RF 2193563, 2002.

9. Ogunsipe A., Chen J.Y., Nyokong T. New. J. Chem. 2004, 28 , 822-827.

10. Lakowicz J.R. In: Principles of Fluorescence Spectroscopy (2nd edition). Kluwer Academic/Plenum Publishers: New York, 1999.

11. Spiller W., Kliesch H., Woehrle D., Hackbarth S., Roder B., Schnurpfeil G. J. Porphyrins Phthalocyanines 1998, 2, 145-158.

12. Kuznetsova N.A., Gretsova N.S., Kalmykova E.A., Makarova E.A., Dashkevich S.N., Negrimovsky V.M., Kaliya O.L., Lukyanets E.A. Russ. J. Gen. Chem. 2000, 70, 133-140.

13 Kazitsina L.A., Kupletskaya N.B. Primenenie UF-, IK, i YAMR spektroskopii $v$ organicheskoy khimii [Application of UV-, IR- and NMR Spectroscopy in Organic Chemistry]. Moscow: Vyssh. shkola, 1971. (in Russ.).

14. Lottner C., Bart K.-C., Bernhardt G., Brunner H. J. Med. Chem. 2002, 45, 2079-2089.

15. Kidani Y., Inagaki K., Iigo M., Hoshi A., Kuretani K. J. Med. Chem. 1978, 21, 1315-1318.

16. Noji M., Hanamura S., Suzuki K., Tashiro T., Kidani Y. Chem. Pharm. Bull. 1986, 34, 2487-2493.

17. Kuznetsova N., Makarov D., Yuzhakova O., Solovieva L., Kaliya O. J. Porphyrins Phthalocyanines 2010, 14, 968-974.

18. Sobbi A.K, Wohrle D., Schlettwein D. J. Chem. Soc. Perkin Trans. 1993, 2, 481-488.

19. Cook M.J., Chambrier I., Cracknell S.J., Mayes D.A., Russell D.A. Photochem. Photobiol. 1995, 62, 542-545.

20. Bonnett R., Martinez G. J. Porphyrins Phthalocyanines 2000 , $4,544-550$. 